\title{
Enhancing Learners' Motivation and Speaking Skill through \\ Cooperative Learning Activities
}

\begin{abstract}
:
The present research aims at investigating EFL learners' motivation and English speaking skill development through the implementation of Cooperative Learning activities at the Department of Letters and English at Constantine University, with a sample of third year Didactics. In order to investigate the relationship between the three variables, we first conducted, at the very beginning of our study, a pre questionnaire that was administered to both of the experimental and the control groups, in order to know the students' views concerning the Oral Expression module and the idea of working in groups. After that, we conducted a pre test for both groups to test the students' level. Next, a six-week teaching experiment was conducted through the implementation of Cooperative Learning activities with the experimental group and the use of individualistic type of learning with the control group. At the end of the treatment, we administered a post test to the experimental and the control groups. The comparison of the results provided by the pre and post tests aims at determining the effect that the Cooperative Learning activities has on the students of the experimental group, as contrasted with the students of the control group who performed the tasks individually. At last, a post questionnaire was administered in the end of the experiment to the experimental group, so as to survey to what extent the Cooperative Learning activities could be useful in bolstering up the learners' motivation, and developing their speaking skill. Additionally, a questionnaire was administered to Oral Expression teachers at the department of Letters and Languages at the University of Constantine, with the intention of discerning their assumptions and points of views regarding the effects of Cooperative Learning activities on students' motivation and speaking skilldevelopment. Overall, the comparison of the pre and post tests' results of both groups revealed that the students who worked cooperatively to perform the tasks assigned to them outscored the students who worked individually to solve a given task. These findings support our hypotheses, and are in the direction of many studies which emphasize that Cooperative Learning activities act as a bridge between motivation and speaking skill development.
\end{abstract}

\begin{abstract}
Introduction :
One of the main aims of Foreign Language learners is to develop their speaking skill in order to be able to communicate smoothly and converse fluently with their interlocutors. As a matter of fact, the speaking skill development varies from one student to another, and it is affected by some internal factors (hesitation, fear, shyness) and other external factors (mainly motivation and classroom activities).
\end{abstract}


In the current article, we put under scrutiny the difficulties that Foreign Language learners are subject to, and the ways that may help in facilitating the speaking skill development and making it more interesting and enjoyable. With these objectives in mind, Foreign Language teachers suggest involving Cooperative Learning activities in Oral Expression classes, as a way to create a friendly and an engaging atmosphere that would reduce anxiety in learners, encourage them to take risks, rise up their autonomy, and mostly motivate them towards learning.

\section{Theoretical Background}

\subsection{Teaching Methods and Approaches}

Foreign Language teachers, the world over, have been increasingly confronted by some learners' unfriendliness towards learning which, in fact, enhanced creativity in them and directed them towards plentiful research projects exploring the several dimensions of teaching. Accordingly, several methods and approaches were put forward, and were adopted by the educational systems in the entire world; however, despite the fact that many of the methods and approaches gained popularity for several years and decades, at times, they were criticized, at other times, and their drawbacks contributed to the emergence of other new methods and approaches. As a matter of fact, every method and approach came with some significant theoretical suppositions. The 1940's and 1950's were characterized by the emergence of Structural Methods, namely, the Grammar- Translation Method, the Direct Method, and the Audiolingual Method. Structural Methods, in fact, focused on inserting systematically organized series of linguistic forms into the students' minds through conditioning. The 1960's, however, were influenced by Chomsky's "Competence" and "Performance" as well as Hymes" "Communicative Competence" that refers to "the aspect of our competence that enables us to convey and interpret messages, and to negotiate meanings interpersonally within specific contexts" (Brown, 2007:219). Bagarić (2007:94) states that, the combination of these two words "Communicative Competence" generates, in fact, one interpretation, that is, "the competence to communicate". In the 1970 's, though, innovativeness gave a significant importance to the affective factors, and brought into play The Designer Methods and Approaches. More clearly, in the seventies, Second Language Learning and teaching witnessed a great progress as scholars centered their attention on Second Language Acquisition studies and became more aware of the fundamental importance that the affective domain plays in language learning. Nunan (1989:97; Brown, 2007:112) chose the term "designer" to refer to these methods, namely, Community Language Learning, along with Suggestopedia, the Silent way, Total Physical Response, and the Natural Approach. However, in the 1980's and 1990's the Communicative Approaches brought the language's communicative properties to light and quickly were adopted by many language 
classes and schools all over the world since they were mainly characterized by authenticity, real-life situations and significant activities. Among those approaches, it is mentioned: Communicative Language Teaching, Cooperative Language Learning, Whole Language, Content-Based Instruction, Task-Based Language Teaching, and Competency-Based Language Teaching.

\subsection{The Speaking Skill}

Indisputably, there is overwhelming evidence corroborating the fact that the extensive improvement universal communication knew by reason of the development of technology, internet, and notably the emergence of social media which contributed a lot in promoting creativity, interaction, and learning through the countless connections made with individuals, over the globe, who share the same interests and goals. Individuals with various nationalities and different mother tongues, most of the time, if not always, choose the English language to transmit their ideas and give their opinions. This potent cause deepened the urge to learn the English language by a mass of people, in general, and EFL learners, in particular, and explains, in one way or another, the rapid growth witnessed in this actual time and epoch, worldwide. Plainly, the English language is characterized by four basic skills: writing, reading, listening and speaking. Yet, the latter is very appealing to, virtually, all the EFL learners whose central aim is to be able to develop their speaking skill and, thus use it smoothly in communication.

Speaking, by definition is "an interactive process of constructing meaning that involves producing and receiving and processing information" (Florez, 1999; in Bailey, 2005:2). In similar vein, Chaney and Burk (1998:13) states: "speaking is the process of building and sharing meaning [...] in a variety of contexts". That being the case, mastering the speaking skill requires a command of characteristics of speaking and a control of language components that are described in the following pyramid: 


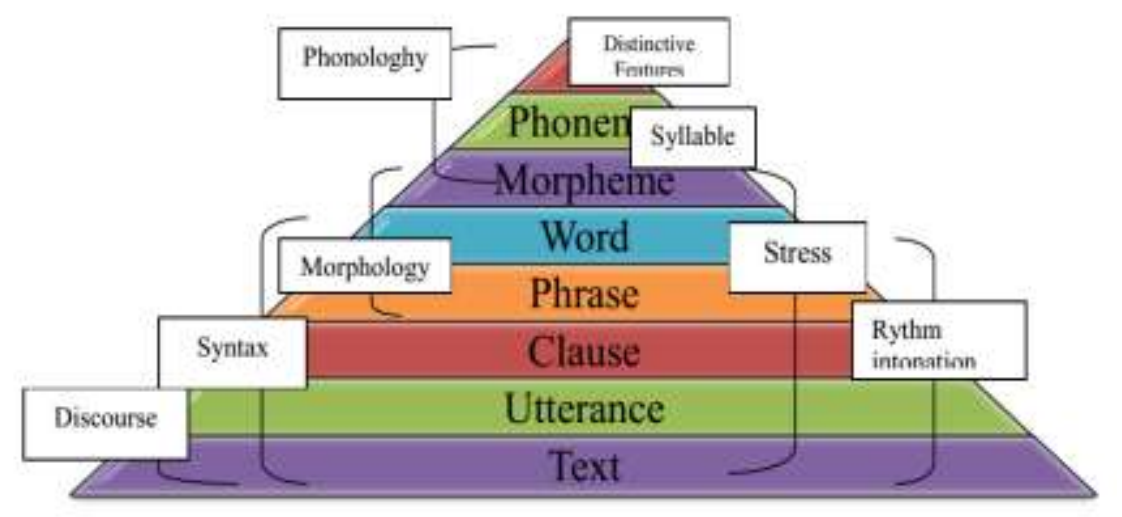

Figure 1.1. Units of Spoken Language (Van Lier, 1995: 15)

To dismiss any misunderstanding, it is important to discern the dichotomies "Language Acquisition" and "Language Learning". When the former refers to "the gradual development of ability in language" through making use of it naturally in communicative contexts with other persons who know the language (Yule, 2006:163), the latter stands for "a conscious process of accumulating knowledge of the features [...] of a language" generally in institutional settings (Yule, ibid.).

According to Oxford (1990), when learning a Foreign Language, learners tend to make use of direct strategies (memory strategies, cognitive strategies, compensation strategies), and indirect strategies (metacognitive strategies, affective strategies, social strategies). Once again, learning a Foreign language requires the learners to identify their learning styles, that are, quoting Keefe (1979:4; in Brown, 2007: 120), defined as "cognitive, affective, and physiological traits that are relatively stable indicators of how learners perceive, interact with, and respond to the learning environment". In simpler terms, Skehan (1991: 288), defines the learning styles as "a general predisposition, voluntary or not, toward processing information in a particular way" (ibid.). In this vein, Hedge (2000:18) states that the learning styles can be defined as "a characteristic and preferred way of approaching learning and processing information."

Brown (2007) notes that the way individuals internalize their milieu determines their styles. To dismiss the understanding, in the internalization process, cognitive, physical and affective domains are incorporated to indicate the learning styles. Individuals, in fact, do not use a single style, but they tend to make use of various ones in relation to the contexts they are in. In a point of fact, a myriad of learning styles was identified over the past few years. 
However, Brown (2007: 121-31) selected five of them, owing to their relevance to teaching. They are: field independence-dependence, left and right brain dominance, ambiguity-tolerance, reflectivity and impulsivity, and visual, auditory, and kinesthetic styles.

Undeniably, all the languages of the world are characterized by encompassing four skills. And the learning of a language is, actually, dependent upon dominating its four skills that are speaking, reading, writing and listening. According to Savignon (1991), the four language skills are described with reference to their "direction" and "modality". By "direction", it is meant to clarify whether the learners are producing or receiving messages. However, by "modality", it is meant to describe the mode or method of transmitting messages. In view of that, speaking and writing are productive skills, whereas reading and listening are receptive skills. While the productive skills engage learners in a variety of activities that help them express their ideas, give their opinions, and share their knowledge, the receptive skills involve them in activities that enhance their understanding to different facts, memorization to new information, and reception to knowledge. In the same line of thought, Brown (2001: 275) states that there is "a natural link between speaking and listening", and there is an exchange of roles between interlocutors that provides them with opportunities to transmit their knowledge, express their ideas, and argue about their opinions. It is worth to repeat that both of the speaking and writing skills are productive. Meaning that, in both of the skills, learners produce the language. Yet, despite this similarity, the "spoken language and written language differ in many ways" (Van Lier, 1995:17). Brown (2001:303) contrasted speaking to writing in terms of permanence, processing time, distance, orthography, complexity, vocabulary, and formality.

Brown (2007: 154-167) noted that there are eight main affective factors that are related to language learning development, in general, and to the speaking skill development, in particular. They are: self-esteem, self-efficacy, willingness to communicate, inhibition, risk-taking, anxiety, empathy, and introversion and extraversion.

In a speaking class, both teachers and learners have to adopt some roles in order for an effective learning to take place. According to Harmer (2001: 275-6) teachers should be prompters, participants, and feedback providers. However, learners should be imitative, intensive, responsive, transactional, interpersonal, and extensive (Brown, 2007).

Assessment, usually, takes place at the end of every term or semester, and the learners' grades determine their success or failure. There are several ways to assess speaking, yet teachers most commonly use interviews (one-onone testing), and role plays or presentations when they adopt group work activities. In this vein, Brown (2001: 395) inserts that the best way to test the learners' oral proficiency “involve $[\mathrm{s}]$ a one-on-one tester/test-taker 
relationship, live performance, a careful specification of tasks to be accomplished during the test, and a scoring rubric that is truly descriptive of ability". Thornbury (2008) identified two ways to assess the speaking skill. He notes that the oral test can be either holistic, meaning that the learner is given a single score after being tested, or analytic, in the sense that every aspect of the task to be performed by the learner is given a score, and the overall score is the sum of those scores. To assess the speaking skill, teachers, usually, opt for the analytic assessment; they use a checklist that contains the aspects of speech that are to be assessed such as fluency, accuracy, content, and so on.

During the language production, learners often use grammatically incorrect utterances, which influence the meaning that is intended to be transmitted. In the 1960's Corder introduced "error analysis" that is "a type of linguistic analysis that focuses on the errors learners make" (Gass and Selinker, 2008:102). In simpler terms, error analysis is a study that deals with the learners' errors with the purpose of understanding and identifying the difficulties that the language learners face through the learning process.

Accordingly, Corder (1981) notes that there is a significant distinction between mistakes and errors; he inserts that mistakes refer to slips of the tongue, which are recognized by the speaker once uttered, and are usually related to fatigue, stress, and so forth. Whereas errors are part of the learning process, and their occurrence is systematic. Errors, in fact, are said to be overt when the utterances in which they occur are grammatically wrong. However, when the intended meaning of an utterance is not what is supposed to be understood, errors are said to be covert. Corder (1981; Gass \& Selinker, 2008) distinguished three types of errors: transfer errors that refer to the negative influence of the mother tongue; analogical errors that refer to the foreign language aspects, and teaching-induced errors that are associated with the methods and the teaching material implemented in teaching. In the same vein, Richards (1971) identified two major types of errors; interlingual errors, and intralingual and developmental errors. The former refers to the mother tongue interference, and the latter refers to errors that are part of the language learning process. In intralingual and developmental errors, learners pass through four main stages: overgeneralization, which is when learners over generalize rules used for particular situations (regular/irregular plural, for instance); ignorance of rule restriction that is the application of various structures when not needed; incomplete application of rules that refers to the teacher's influence on the students' answers; and false concepts hypothesized that is related to the misunderstanding of language aspects.

Hedge (2000) notes that teachers have to correct the learners' developmental errors taking into account their affective side. In other words, teachers, when correcting their learners' errors, they have to use positive feedback and to create a balance between "correction" and "encouragement". 


\subsection{Motivation}

Motivation has always been a catch-all term in determining success or failure in accomplishing a given task, in general, and a key factor in language learning, in particular. To explain the complexity of motivation, researchers put forward a myriad of definitions that all center around the fact that motivation is "what gets [one] going, keeps [one] going, and determines where [one is] going to go" (Slavin, 2003:329).

In the light of that, several approaches and theories have seen the light in relation to the main schools of thoughts: 1) the behavioristic perspective, which perceives motivation in terms of external processes and reinforcement. More to the point, the results obtained after having conducted several scientific experiments on animals in laboratories proved that the behavior develops as a reaction to external stimuli. Accordingly, two main theories were introduced: Drive Reduction Theory, and Conditioning Theories. 2) The humanistic perspective, which identifies motivation in relation to needs to be satisfied. It is important to state here that one of the most influential humanistic theories is Abraham Maslow's Hierarchy of Needs, which was first introduced to the world in 1943, and which perceives motivation as "a construct" in which eventual achievement of goals may occur only through a hierarchy of needs (Brown, 2007:169). 3) The cognitive perspective, which stresses the fundamental role of mental structures and information processing. Advocates of the cognitive perspective assume that individuals are in command of their own acts, in the sense that individuals make decisions and choices to attain their desired objective. In this vein, Williams and Burden (1997:119) argue that individuals "have choice over the way in which they behave and, therefore, have control over their actions".

Another arguable dichotomy related to the field of motivation is that of intrinsic and extrinsic motivation. Educational psychologists explained intrinsic motivation as being the internal appreciation and pleasure individuals feel when they succeed in accomplishing a given task (Williams \& Burdens, 1997: 136), and extrinsic motivation as being stimulated by the anticipation of reward (Vellerand, 1997; in Dorneyi, 1998: 121).

The shift of perspectives in the 1990's emphasized the salient dominance motivation has in the field of education. It was believed that motivation can have instrumental orientations (individual's desire for achieving academic goals) or integrative (the individual's desire to integrate into the culture of the language being learned).

Several frameworks were suggested to explain motivation in language learning, and several teaching and learning motivational strategies were put forward to be used in language classes to facilitate the learning process. According to Guilloteaux (2007: i), motivational strategies are believed to be "directly linked to increased levels of the learners' motivated learning behavior 
and their motivational state". In simpler terms, motivational strategies encompass the techniques that teachers implement in order to enhance the students' motivation, and the strategies that the learners adopt to ensure their own motivation. Accordingly, motivational strategies are classified in terms of motivational teaching strategies that are, according to Guilloteaux and Dornyei (2007:3), "Instructional interventions applied by the teacher to elicit and stimulate student motivation", and motivational learning strategies that are "self-regulating strategies that are used purposefully by individual students to manage the level of their own motivation" (ibid.)

\subsection{Cooperative Learning}

Cooperative Learning has gained popularity over the past few decades for the enthusiasm and variety that it brings when implemented in language classes. According to Slavin (1995:2), Cooperative Learning is when "students work in small groups to help one another learn academic content". The idea of getting learners to work together to attain common goals and improve their academic achievements needs the presence of five main elements, which are: positive interdependence, face to face interaction, individual and group accountability, interpersonal and small-group skills, and group processing (Johnson \& Johnson, 1994). In order for the teacher to get his/her learners to work together to do the assigned tasks, $\mathrm{s} /$ he has to break them into groups. Accordingly, Macpherson (2007:11) identified six possible combinations are possible. They are: instructor assigned groups; randomly assigned groups; social integration groups; subject-matter related groups; 5) geographic groups; and self-selected groups.

It should be stated that research on Cooperative Learning was guided by three major theoretical perspectives: social interdependence, cognitive developmental, and behavioral. Each of these perspectives helped in the understanding of Cooperative Learning regarding its implementation in language classes.

In Cooperative Learning, the teacher implements several methods that are believed to contribute to the enhancement of the learners' academic achievements, getting the learners more involved and more engaged, promoting the learners' interaction, boosting the learners' self-esteem, and enthusing the learning environment. These methods are: the Jigsaw, group investigation, learning together, the structural approach, the student-team achievement divisions, the teams' games tournaments, and team- assisted individualization or team- accelerated instruction (Slavin, 1995).

Although Cooperative Learning has many advantages, such as the enhancement of learners' academic achievement, the emphasis of learners' engagement, the generation of positive interaction, the endorsement of selfesteem, and the creation of a enthusiastic learning environment, it is important 
to look at its pitfalls that can be associated to group dynamic dilemmas, uneven workloads, and classroom management challenges in order to avoid them.

\section{Practical Background}

To improve the teaching and learning processes, it is significant to carry out pedagogical researches that are, as defined by Singh (2006:1): "simply the process of arriving at dependable solutions to a problem through the planned and systematic collection, analysis and interpretation of data." In other words, to accomplish the requisite objectives and meet up with the researcher's expectations, a research ought to be methodical and determined.

To investigate the effects of the cooperative learning activities on learners' motivation and speaking skill development, three main tools are used: the questionnaire, the test, and the experimental design.

The target population with whom the present research is carried out involves one grade level, that is to say, it is represented by third year students of English (Didactics) at the Department of Letters and the English Langauge, at the University of Frères Mentouri, Constantine, and that is represented by 280 students making up five (5) groups where female students outnumber male students.

In this research, one group (56 students) is selected randomly from the five ones at the beginning of the year (October 2014). The sample represents 28 students each; one control and another experimental, each class meets three instructional Oral Expression hours per week divided up into two sessions of one hour and a half each. Students, in the control group, perform the activities proposed by the teacher individually; however, students in the experimental group complete the tasks in sub groups.

\subsection{The Questionnaires}

\subsubsection{The Pre and Post Questionnaires}

The questionnaire is self-completed; it is composed of several questions. Some of the questions are of the multiple choice type, where students are supposed to tick $(\checkmark)$ the corresponding box, others are dichotomous (yes/no questions), and some others are open-ended. As mentioned earlier, the students' answers serve to investigate their opinion about the O.E. module and their perceptions in relation to the extent to which they accept the idea of working in groups.

The pre questionnaire is administered to both experimental and control groups, and it divided into seven sections that deal with students' personal information; students' motivation; the students' attitudes in their oral expression class; the students' personality; the teacher's attitudes; the learning environment; and the students' reactions towards group work.

After having analyzed the feedback of the pre questionnaire that the participants provided, we became more aware of their perceptions and their needs. The participants' answers, stressed the importance of implementing 
various activities (songs, movies, language games, individual presentations, and role plays) as mentioned in (Q19). Because, as portrayed in (Q16), the majority of their oral expression classes are used either discussions (60.72\%) or individual presentations (39.28\%) and such activities, as stated in (Q17) and (Q18), are of assistance, but are not that motivating (44.64\%) and do not contribute much in the development of their speaking skill (48.22\%). In actual fact, that is what explains the answers they provided in (4Q) and (Q5) where the majority of the participants (75\%) affirmed that they do not enjoy much their O.E. classes, and they "sometimes" (55.35\%) and "rarely" (32.14\%) participate. Furthermore, the results obtained in (Q21) reveal that the majority of participants $(66.07 \%)$ show their disinterest towards the idea of working in groups; they believe that their colleagues' performance is not satisfactory, besides, the difference of opinions lead to some disagreements.

The post questionnaire is administered to the experimental group at the end of the experiment, and is divided into seven sections that echo the main areas discussed earlier and help in validating the perceptions stated earlier concerning the effects of cooperative learning activities. The sections deal with students' personal information; students' attitudes towards the speaking skill the learning environment; students' estimations to the implementation of cooperative learning activities; the cooperative learning activities; the effects of cooperative learning activities on students; and further suggestions.

The analysis of the data obtained from the participants that undertook the post questionnaire revealed that the cooperative learning activities had an important effect on the students' motivation towards the development of their speaking skill. The participants' answers in (Q7) reveal that the largest majority of them $(92.86 \%)$ appreciated a lot the idea of implementing the C.L. activities in their oral expression class. The participants' answers in (Q5) reveal that (96.42\%) of them believe working cooperatively create an exciting atmosphere. As portrayed in (Q8) and (Q9), a large category of participants $(89.28 \%)$ affirms that working cooperatively is very motivating, and contributes a lot in the development of their speaking skill $(96.42 \%)$. The majority of participants $(96.42 \%)$ seem to be aware of the positive effects of the C.L. activities they had as stated in (Q15) and (Q16); they, accordingly, believe that working cooperatively is of assistance in improving their speaking skill, becoming less shy and more confident, learning how to communicate with each other easily and respecting each others' ideas. The participants' answers in (Q7) reveal that the largest majority of them $(92.86 \%)$ appreciated a lot the idea of implementing the C.L. activities in their oral expression class which is completely the opposite of what the results of (Q21) of the pre questionnaire revealed; (66.07\%) of the participants disfavored the idea of working in groups before the experiment, but seem to have changed their opinion after having been through it for the reasons mentioned earlier. 


\subsubsection{The Teachers' Questionnaire}

The teachers' questionnaire is composed of twenty (20) questions given to a sample of fifteen teachers of Oral Expression. Some of the questions are of the multiple choice type, others are dichotomous (yes/no questions), and some others are open-ended. The teachers' answers are of a potent assistance in looking at the effects of Cooperative Learning activities on EFL students' motivation and speaking skill.

The questionnaire is divided into six sections: section one deals with the teachers' personal information, section two is assigned to deal with teaching the speaking skill, section three is allocated to the teachers' attitudes towards cooperative work, section four speaks about the students' motivation, section five encompasses the teachers' role when putting the Cooperative Learning activities into practice, and section six is devoted to the teachers' further suggestions.

The analysis of the Teachers' Questionnaire feedback displays a significant agreement with the suppositions and the assumptions set formerly, which state that cooperative work enhances students' motivation and helps them develop their speaking skill.

In (Q8), (05) teachers, making up (33.3\%), stated that they implement cooperative work in their O.E. class. Among them, (80\%) believe that implementing cooperative work affects the students' performance "very much" (Q9), while (20\%) think that cooperative work "somehow" affects the students' performance.

Again, in (Q8), (10) teachers, making up (80\%), affirmed that they do not implement cooperative work in their oral expression class; the majority of them, making up (10\%) related the fact that they do not arrange cooperative work in their oral expression classes to a major problem, that is: overcrowded classes (Q10).

Teachers seem to be aware of the effects cooperative work has on students; in (Q12) the vast majority of them, making up (86.66\%), believe that cooperative work is motivating, while the remaining minority, making up (13.34\%), think the opposite. The former portion believes that working cooperatively helps the learners get more involved in classroom activities and helps them be more creative. Whereas, the latter proportion, making up (13.34\%), think that cooperative work is not that motivating because it is not much appreciated on the part of students. Besides, they think that implementing cooperative work needs time and a good classroom management, and that is easier said than done with overcrowded classes.

Evidently, mistakes and errors are part of the learning process, yet some students seem to be sensitive when they are corrected. All teachers, who took part in answering this questionnaire, believe that positive feedback is very important and enhances students' motivation (Q14). They believe that 
providing students with positive feedback encourages them in taking part in classroom activities since it lessens their anxiety and hesitation (Q15).

Unquestionably, praise is a valuable incentive in prompting the learners' motivation. In response to $(\mathrm{Q} 16) \&(\mathrm{Q} 17)$, all the participants, making up $(100 \%)$ agreed on the fact that praise is motivating to students. They affirm that praise helps students be more confident and more aware about their real abilities, and thus helps them in promoting their educational achievements.

Motivation is thought to be essential in all kinds of learning. All the teachers, who participated in answering the questionnaire, affirmed the importance of the effects that motivation has on students' performance (Q18).

It has been determined that working in small groups magnifies the students' role and minimizes the teachers' role (Brown, 2003). Correspondingly, all the participants believe likewise and believe that the teacher is there to guide and to manage the class (Q19).

\subsection{The Pre and Post Tests}

The pre test was conducted at the beginning of the experiment to both of the control and the experimental groups in order to evaluate the students' level. The learners were notified a week earlier about it and were given a full description of the task to be performed; on the teacher's desk are put seven strips of paper, on each one of them is written a different open ended quote of either an author, a poet, a philosopher or even a politician. After coming individually into the classroom, the students mix that bunch of the seven strips of paper and pick up one of them, read the content carefully, then argue and give their points of view through their own perspectives or through their own experiences in life. Their pronunciation, fluency, grammatical accuracy, vocabulary use, and content are evaluated; four (4) points for each aspect.

The pre test was administered with the purpose of identifying the students' level and needs. The results displayed in the graph below (graph 2.1.) show that both the control and the experimental groups have approximately the same level in their oral performance. Few discrepancies are noted, yet on the whole, both of the groups' oral performances are nearly the same. 


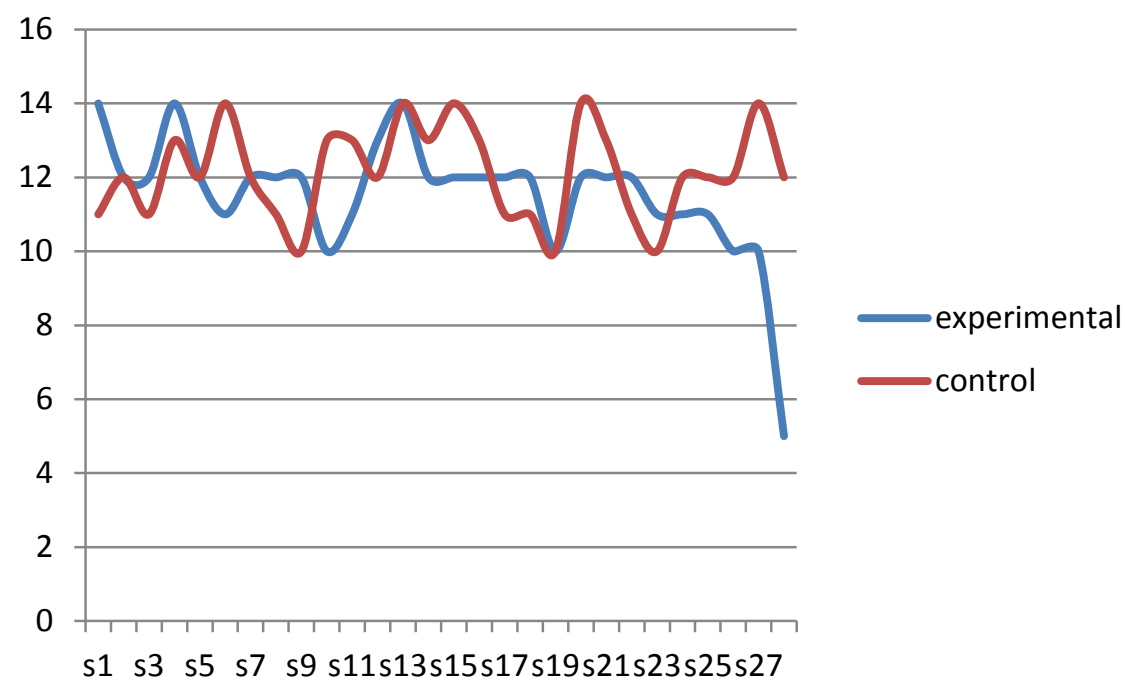

Graph 2.1. A Representation of Oral Performances in The Experimental and The Control Groups -Pre Tests

After having conducted the experiment, a post test is administered to both of the control and the experimental groups in an attempt to check whether there was any improvement in the students' final productions as compared to their initial ones. The graph below (2.2.) shows that the experimental group's performance is slightly better as compared to the means of the control group in terms of performances and this result goes somehow in the direction of our hypothesis. 


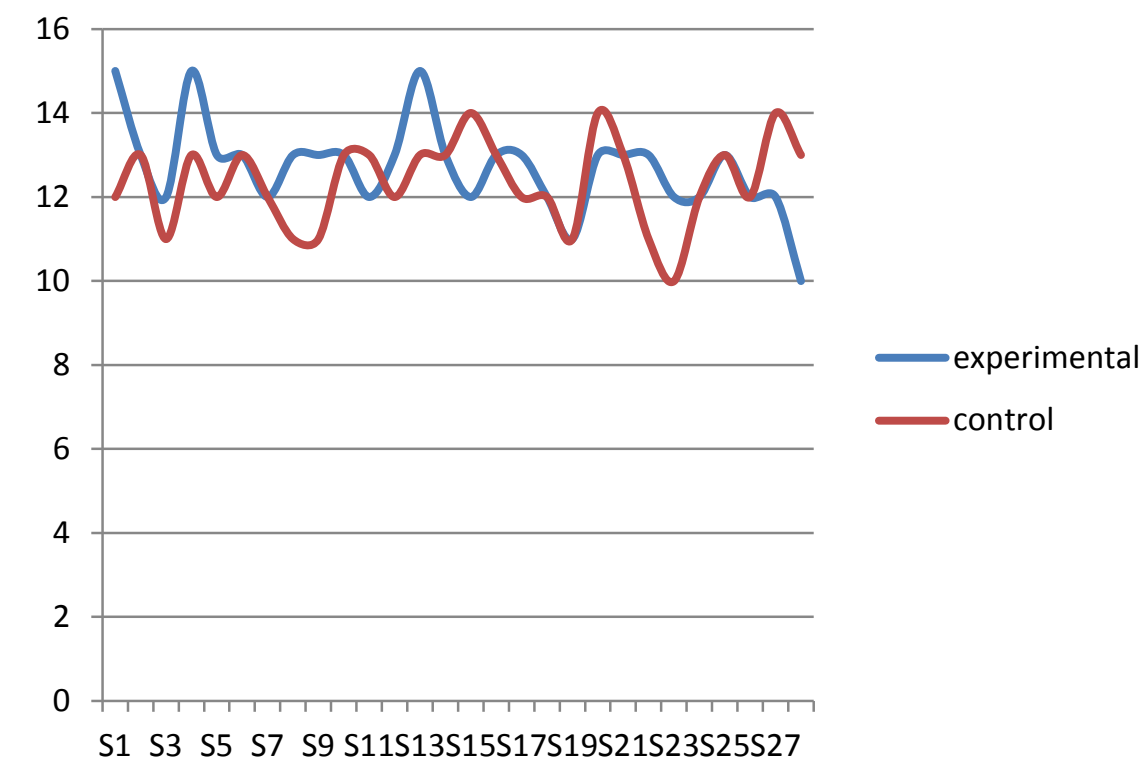

Graph 2.2. A Representation of Oral Performances in The Experimental and The Control Groups- Post Tests

\subsection{The Treatment}

In the table below (table 2.1.) are exposed the activities used in the experiment with both of the experimental and the control groups as well as the main objectives of the activities and the time they take. 


\begin{tabular}{|c|c|c|}
\hline \multirow{2}{*}{ Activity } & \multicolumn{2}{|l|}{ Task } \\
\hline & Experimental Group & Control Group \\
\hline $\begin{array}{lr}\text { Listening } & \text { to } \\
\text { Pharell } & \\
\text { Williams' } & \\
\text { (Happy) } & \end{array}$ & $\begin{array}{l}\text { Listening to the song } \\
\text { for several times then } \\
\text { filling the blanks } \\
\text { cooperatively in the } \\
\text { lyrics' sheet. }\end{array}$ & $\begin{array}{l}\text { Listening to the song } \\
\text { for several times then } \\
\text { filling the blanks } \\
\text { individually in the } \\
\text { lyrics' sheet. }\end{array}$ \\
\hline $\begin{array}{l}\text { Watching the } \\
\text { Movie "Pride } \\
\text { and Prejudice" }\end{array}$ & $\begin{array}{l}\text { Watching the movie } \\
\text { then analyzing the } \\
\text { plot cooperatively. }\end{array}$ & $\begin{array}{l}\text { Watching the movie } \\
\text { then analyzing the } \\
\text { plot individually. }\end{array}$ \\
\hline Chain Story & $\begin{array}{l}\text { Every student in the } \\
\text { group adds a sentence } \\
\text { to create a group } \\
\text { story. }\end{array}$ & \\
\hline Heads and Tails & & $\begin{array}{l}\text { Every student gives a } \\
\text { word whose end is the } \\
\text { beginning of another. }\end{array}$ \\
\hline \begin{tabular}{|l|} 
Introducing \\
Role Plays
\end{tabular} & $\begin{array}{l}\text { Every group was } \\
\text { given a situation to } \\
\text { act on the spot. }\end{array}$ & \\
\hline Role Plays & $\begin{array}{l}\text { Every group writes } \\
\text { the scenario of the } \\
\text { play that they } \\
\text { perform. }\end{array}$ & \\
\hline $\begin{array}{l}\text { Introducing } \\
\text { Oral } \\
\text { Presentations }\end{array}$ & & $\begin{array}{l}\text { Every student selects } \\
\text { a topic of his/her } \\
\text { choice to present } \\
\text { orally } \\
\text { individually. }\end{array}$ \\
\hline \begin{tabular}{|l|} 
Oral \\
Presentations
\end{tabular} & & $\begin{array}{l}\text { Every student selects } \\
\text { a topic of his/her } \\
\text { choice to present } \\
\text { orally } \\
\text { individually. }\end{array}$ \\
\hline
\end{tabular}

Table 2.1. The Activities Used in the Experiment.

In the table below (table 2.2.) are displayed the global averages of both of the experimental and control groups after having taken the treatment. 


\begin{tabular}{|c|c|c|c|}
\hline \multicolumn{2}{|l|}{ Activities } & \multirow{2}{*}{$\begin{array}{l}\text { Experimental } \\
\text { Group } \\
13.64 / 20\end{array}$} & \multirow{2}{*}{$\begin{array}{l}\text { Control } \\
\text { Group } \\
11 / 20\end{array}$} \\
\hline Activity 1 & $\begin{array}{l}\text { Listening to the song "Happy" of } \\
\text { Pharell Williams }\end{array}$ & & \\
\hline Activity 2 & $\begin{array}{l}\text { Watching the movie "Pride and } \\
\text { Prejudice" }\end{array}$ & $14.32 / 20$ & $11.65 / 20$ \\
\hline \multirow[t]{2}{*}{ Activity 3} & Chain Story (a language game) & $13.46 / 20$ & \\
\hline & $\begin{array}{l}\text { Heads and Tails (a language } \\
\text { game) }\end{array}$ & & $11.86 / 20$ \\
\hline \multirow[t]{3}{*}{ Activity 4} & $\begin{array}{l}\text { Introducing role plays through } \\
\text { simulations }\end{array}$ & $12.03 / 20$ & \\
\hline & & $12.60 / 20$ & \\
\hline & Staging role plays & $13.21 / 20$ & \\
\hline \multirow[t]{2}{*}{ Activity 5} & Introducing oral presentations & & $12.21 / 20$ \\
\hline & Oral presentations & & $13.28 / 20$ \\
\hline \multicolumn{2}{|c|}{ Total Averages } & $13.21 / 20$ & $12 / 20$ \\
\hline
\end{tabular}

Table 2.2. Global Averages

In the first activity, both of the groups were required to listen several times to the song "Happy" of Pharell Williams, and try to find the correct words to fill in the gaps on the lyrics sheet previously handed to them. The song used in this activity was chosen by the students for the positivity it spreads. It is entitled "Happy", and it is sung by Pharell Williams. In this activity, the learner's listening, performance of the task, motivation and participation, and oral performance are evaluated along with the experimental group working cooperatively and the control group working individually. Interest and enthusiasm were demonstrated in both of the experimental and control group's behaviors, yet the experimental group over scored the control group. The experimental group scored $(13.64 / 20)$, whereas the control group scored $(11 / 20)$.

In the second activity, learners were required to watch "Pride and Prejudice" based on the novel of Jane Austen, and to analyze the plot at the end of the session. The learners' comprehension, performance of the task, motivation and participation, and oral performance were evaluated. Again, unlike the experimental group, which performed the task cooperatively, the control group performed it individually. Once again, learners of both groups enjoyed watching the movie and showed a considerable amount of motivation when doing the task. However, despite the difference in the scores of both of 
the experimental group $(14.32 / 20)$ and the control group $(11.65 / 20)$, an improvement is noticed in the scores of both groups as compared with the scores obtained in the first activity.

The third activity comprises the implementation of two language games: the chain story with the experimental group (working cooperatively to create a story), and heads and tails with the control group (working individually to find the correct word). In this activity, the content, the vocabulary, the performance of the task, the learners' motivation and participation, as well as their oral performance are evaluated. Eagerness and motivation were present although the activity, yet again, the results displayed in the table below (table 6.37.) demonstrate that the experimental group over scored the control group. More precisely, the experimental group scored (13.46/20), whereas the control group scored (11.86/20). The results also demonstrate that there is a regression in the score of the experimental group in this activity as compared to the score obtained in the previous activity (14.32/20). A slight progression in the score of the control group is noticed in this activity as compared to the score obtained in the previous activity $(11.65 / 20)$.

The fourth activity, that is role playing, is exclusively used with the experimental group. More clearly, learners of the experimental group are required to break into groups and to choose the ones they would like to work with (social integration groups) to write and perform their own plays. Yet, before implementing this activity, simulations are implemented in order to get the learners acquainted with the idea of jointing their ideas and skills to perform in front of a mass of people (classmates). The content of the plays, the performance of the task, the groups' motivation and participation, and their oral performance, as well as their cooperation are evaluated. In simulations, learners are asked to suggest a problem to solve, and choose a group for each situation. Hesitation and reluctance are very present at the beginning (12.03/20), which requires another session in an attempt to make the learners more comfortable with the idea of performing in front of their classmates. In the second session, the aforementioned assumptions are attained, meaning that the learners are less anxious and more confident, and scored better than in the first performance $(12.60 / 20)$. On the basis of the previous considerations, staging role plays, at that juncture, was possible and doable.

Learners of the experimental are really motivated and creative, their enthusiasm is apparent in the themes they wrote, in their performance, and in their costumes. The global average of the scores they obtained is $(13.21 / 20)$.

The fifth activity is solely implemented with the learners of the control group, and which comprises the oral presentations. In oral presentations the content of the presentations, as well as the learners' performance of the task, the learners' motivation and participation, and their oral performance are evaluated. With the purpose of making the learners be more familiar with the 
idea of public speaking, a session is devoted to introduce oral presentations. Learners are required to summarize a story they read, a movie they watched, or simply speak about one of their anecdotes in a short period of time. Some of the learners seems to be acquainted with this activity, and the global score of their short presentations is $(12.21 / 20)$.

The learners of the control group show a great deal of interest and motivation when they present their topics, which treat some scientific and biological matters, at times, and social, psychological, and spiritual at other times. The global average of their presentations is (13.28/20).

As demonstrated in the table below (table 2.2.), the total average of the experimental group is $(13.21 / 20)$, whereas the total average of the control group is (12.20/20). A reason that may explain that difference in scores could be related to the fact that when working cooperatively to attain common goals, learners tend to encourage and help each other, and thus motivation is amplified. However, when learners work individually, interaction is lacking and thus motivation remains constant or varies within the same learner.

In the present article, a t-test was conducted in the end of the experiment in order to investigate the effects of cooperative learning activities on the students' motivation and speaking skill development.

T-test is a statistical test that is frequently brought into play in various scientific experiments to check if the difference in the means of two groups is significant or not. The formula:

$$
t_{N 1+N 2-2}=\frac{\left(\bar{X}_{1}-\bar{X}_{2}\right) \sqrt{\left.N_{1}+N_{2}-2\right) N_{1} N_{2}}}{\sqrt{\left(N_{1 S 1^{2}}+N_{2 S 2^{2}}\right)\left(N_{1}+N_{2}\right)}}
$$

The level of significance set for a t-test, one tailed, is (0.05/2), making (2.39) the critical value required. The obtained value of $t$ is (4.18) that is much higher than the required value of $t(4.18>2.39)$ with 54 degrees of freedom obtained through this formula $\mathrm{N} 1+\mathrm{N} 2-2$. Hence, $28+28-2=54$.

In view of that, the results obtained are "statistically significant", and confirm that the implementation of the cooperative learning activities do enhance EFL students' motivation and speaking skill.

\section{Conclusion}

All things considered, it is brought to a close that the research's results reassure the assumptions and suppositions set in relation to the positive impact that the Cooperative Learning activities have on EFL students' motivation and their speaking skill. Therefore, Foreign Language teachers are recommended to implement the cooperative learning activities more frequently and more adequately. 


\section{References}

Bagarić, V. (2007). Defining communicative competence. Metodika, 8, 94-103.

Baily, K. M. (2005). Practical English language teaching: Speaking. NY: McGraw-Hill.

Brown, H. D. (2001) Teaching by principles: An interactive approach to language pedagogy. San Francisco: Pearson Education.

Brown, H. D. (2007) Principles of language learning and teaching ( $5^{\text {th }}$ ed.). NY: Pearson Education.

Chaney, A.L., and T.L. Burk. (1998). Teaching Oral Communication in Grades $K-8$. Boston:

Allyn\&Bacon.

Corder. S. P. (1981). Error and interlanguage. Great Britain: Oxford University Press.

Dornyei, Z. (1998). Motivation in second and foreign language learning. Cambridge: Cambridge University Press.

Florez, M. A. C. (1999). Improving adult English language learners' speaking skills. Washington, DC: Clearinghouse for ESL Literacy Education. (Eric Document Reproduction Service No. EDO-LE99-01).

Gass, S. M. \& Selinker, L. (2008). Second language acquisition: An introductory

course. New York: Routledge.

Guilloteaux, M. J. (2007) Motivating language learners: a classroom-orientated investigation of teachers' motivational practices and students' motivation. $\mathrm{PhD}$ thesis, University of Nottingham.

Guilloteaux, M. J., \& Dornyei, Z. (2008). Motivating language learners: A classroom oriented investigation of the effects of motivational strategies on students' motivation. TESOL Quarterly, 42(1), 5577.

Harmer, J. (2001). The practice of English language teaching ( ${ }^{\text {rd }}$ ed.) UK: Pearson Education Limited.

Hedge, T. (2000). Teaching and learning in the language classroom. Oxford \& NY: Oxford University Press.

Johnson, D. W., Johnson, R. T., \& Holubec, E. J. (1994). The nuts and bolts of cooperative

Retrieved from:

learning. Minnesota Minnesota: Interaction Book Company.

https://en.wikipedia.org/wiki/Cooperative_learning\#cite_note-8 
Kefee, J. (1979). Student learning styles: diagnosing and prescribing programs. Reston, VA: National Association of secondary School Principals.

Lier, V. L. (1995). Introducing language awareness. London: Penguin.

Nunan, D. (1989), Designing tasks for communicative classroom. New York. Cambridge University Press.

Richards, J.C. (1971). Error Analysis and Second Language Strategies. Quebec: ICRB.

Savignon, S. J. (1991). Communicative language leaching: The state of art. TESOL Quarterly, 25(2).

Singh, K. Y. (2006). Fundamental research methodology and statistics. New Delhi: New Age International (P) Ltd., Publishers.

Skehan, P. (1998). A Cognitive approach to language learning. Oxford: Oxford University Press.

Slavin, R. (1995). Cooperative learning: theory, research, and practice. $\left(2^{\text {nd }}\right.$ ed.)

Allyn \& Bacon: A Simon \& Schuster Company. Needham Heights, Massachusetts.

Slavin, R. E. (2003). Educational psychology: Theory and practice ( $7^{\text {th }}$ ed.). Boston: Pearson Education Inc.

Vallerand, R. J. (1997). Toward a hierarchical model of intrinsic and extrinsic motivation. Advances in Experimental Social Psychology (Vol. 29, pp. 271-360). San Diego: Academic Press.

Williams, M. \& Burden, R. L. (1997). Psychology of language teachers: A social

constructivist approach. UK: Cambridge University Press.

Yule, G. (2006). The Study of Language. Cambridge: Cambridge University Press 